\author{
Mateusz Kuczyk \\ Piotr Jędrzejewski \\ Pawet Zaluski \\ Politechnika Gdańska
}

\title{
The concept of suspended urban rail vehicle
}

\section{Koncepcja miejskiego pojazdu kolei podwieszanej}

\begin{abstract}
The main topic of this article is the description of a concept of the authors' suspended rail vehicle. Firstly, the existing solutions where analysed with determination of their disadvantages and advantages. Subsequently, the proposed construction was described in the fields of: rolling stock build, suspension construction and guidance system. This article is based on authors' master thesis: „The concept of suspended railway engine wagon”, conducted on Mechanical Engineering Faculty of Gdansk University of Technology.
\end{abstract}

Niniejsza publikacja została poświęcona szczegółowemu opisowi proponowanej przez autorów koncepcji podwieszanego pojazdu szynowego. W pierwszej kolejności przeanalizowano istniejace rozwiazania, wraz ze wskazaniem ich podstawowych wad i zalet. Następnie opisano proponowana konstrukcje $w$ zakresie: budowy wagonu, sposobu jego zawieszenia oraz prowadzenia po zadanym torze ruchu. Artykut ten powstat na podstawie pracy dyplomowej pt. „Koncepcja wagonu silnikowego kolei podwieszanej”, na wydziale Mechanicznym Politechniki Gdańskiej.

\section{INTRODUCTION}

A constantly growing population of urban areas and connected with that transport system overload are the main reasons for new types of mass transport searching. Moreover, this new means of transport should be: independent from traffic system, safe and ecological. Known and widely used solution, compliant with such requirements, is underground railway. However, it's characterized by one main disadvantage, time- and money-consuming build, which could be even impossible because of the geological conditions.

Another, less popular solution is monorail, which vehicles move several meters above a ground level. This type of railway, like metro, is fully independent from a traffic system, also its infrastructure is less expensive (about $50 \%$ with equal maintenance costs) and shorter to build than in case of an underground railway [1]. It also requires minimal: interference in the city infrastructure and ground space (only for guideway and stations columns) or it could be a real tourist attraction.

Furthermore, this kind of vehicles can be easily equipped with autonomous system - APM (Automated People Mover). Obviously, suspended railway has got some drawbacks, like: less total capacity than metro, incompatibility with other means of transport or restricted route selection due to building density in cities (although, there are known cases in which station can be situated inside a building).

Monorail vehicles can be divided into two main groups: suspended type (car body is situated under the guideway) and straddle type (car body is situated above the guideway).

The second one is more commonly used, that is a

\section{WSTĘP}

Wraz ze stale rosnącą populacją aglomeracji miejskich oraz wiążącym się z tym nadmiernym obciążeniem ich systemów komunikacyjnych, poszukiwane są nowe środki transportu zbiorowego, niezależne od ruchu ulicznego, bezpieczne i ekologiczne. Od dawna znanym i szeroko wykorzystywanym rozwiązaniem, spełniającym powyższe kryteria, jest metro. Jednak charakteryzuje się ono podstawową wadą, czasochłonną i kosztowną budowa, która dodatkowo może być niemożliwa do przeprowadzenia ze względu na warunki geologiczne.

Innym znanym, ale zdecydowanie mniej rozpowszechnionym rozwiązaniem jest kolej jednoszynowa, której pojazdy poruszają się po specjalnych estakadach nad powierzchnia gruntu. Kolej tego typu, podobnie jak metro, charakteryzuje się całkowitą niezależnością od ruchu ulicznego, ale koszt budowy jej infrastruktury jest o około $50 \%$ mniejszy (przy porównywalnych kosztach eksploatacyjnych) oraz zdecydowanie krótszy niż w przypadku metra [1]. Wymusza ona również mniejszą ingerencję $\mathrm{w}$ istniejącą infrastrukturę naziemna, zajmuje minimalną powierzchnię gruntu (jedynie filary estakad i stacji) oraz może stanowić prawdziwą atrakcję turystyczną.

Ponadto pojazdy tego typu moga podlegać łatwej implementacji systemów autonomicznych - APM (z ang. Automated People Mover). Oczywiście kolej ta ma również wady, jak np.: mniejszą od metra całkowita pojemność, całkowitą niekompatybilność z innymi środkami transportu czy ograniczony wybór trasy spowodowany gęstą zabudową miast (chociaż znane sa przypadki umiejscowienia stacji wewnątrz budyn$\mathrm{ku})$. 
result of: simpler construction, generally higher capacity and lower infrastructure costs. The same level of guideway beam above the ground is obtained by

shorter columns, however suspended vehicles are characterized by one major advantage - running surfaces are protected inside a guideway beam from weather conditions that allows safety and traction properties improvement. For that particular reason, this article focuses on the suspended railway.

\section{REVIEW OF AN EXISTING SOLUTIONS}

In the whole world only two basic suspended railway systems can be highlighted: Eugen Langen and SAFEGE, which are used in only three urban public transport lines. Obviously, such railways are also used in amusement parks (e.g. Ueno Zoo Monorail in Tokyo city) or at airports (e.g. H-bahn in German city of Dusseldorf), where could be applied another technical solutions but they aren't described in this article.

\subsection{Eugen Langen system}

The historical beginnings of monorails are dated back to the $1820 \mathrm{~s}$, although a real milestone in their development was an opening of a suspended monorail line between Erbelfeld and Barmen in 1901 in Germany. In 1929 both cities with another five towns were merged into one city of Wuppertal, which is now located in German federal state of North RhineWestphalia.

In that time monorail (constructed by Eugen Langen), which had been successfully running for almost thirty years, became the first urban line of such kind. Nowadays so-called Schwebebahn (from German suspended railway) is still operating as a unique type of transport.

In its long history, there was only one serious accident (5 fatalities and 47 injured), which was caused by incautious worker who left his tools on a track. This statistic proves a high safety level of monorail [3].

In this particular system vehicle car body is asymmetrically suspended on two-wheel bogies under the track. Double flanged steel wheels prevent derailment. Asymmetrical suspension isn't stable, so the car body oscillates around its support point. Maximal swing angle is limited, in normal service, to $15^{\circ}$. Two rails (Wuppertal line is bidirectional) are fixed, 4 meters apart, to steel girders, which are connecting 464 supporting frames (without depots). A shift of the vehicle motion direction is realized by transfer tables and swivel arms. At the moment Wuppertal vehicle fleet consist of 31 vehicles of 15th generation, manufactured by Vossloh Kiepe (Fig. 1), which technical data according to $[3,4]$ are presented in Table 1 [3].
Wśród pojazdów kolei jednoszynowej można wyróżnić dwa podstawowe typy, to jest kolei podwieszaną (z ang. suspended type; pudło wagonu umiejscowione jest powyżej toru).

Drugi z wymienionych rodzajów jest bardziej rozpowszechniony, co wynika z prostszej konstrukcji, generalnie większej pojemności oraz niższych kosztów budowy infrastruktury. Do umiejscowienia toru na zadanej wysokości wykorzystywane są filary o mniejszej długości, jednak pojazdy podwieszane charakteryzuje jedna, podstawowa zaleta - całkowite zakrycie toru przed warunkami atmosferycznymi, pozwalające na poprawę bezpieczeństwa i własności trakcyjnych. Z tego względu niniejsza praca została poświęcona kolei podwieszanej.

\section{PRZEGLĄD ISTNIEJĄCYCH ROZWIĄZAŃ}

Na świecie można wyróżnić dwa podstawowe systemy kolei podwieszanej: Eugen Langen i SAFEGE, które znalazły zastosowanie jedynie $\mathrm{w}$ trzech systemach komunikacji miejskiej na całym świecie. Oczywiście kolei tego typu stosowana jest również $w$ parkach rozrywki (np. Ueno Zoo Monorail w japońskim Tokio) czy na lotniskach (np. H-bahn w niemieckim Dusseldorf), gdzie mogą być stosowane inne rozwiązania techniczne, niebrane pod uwage w niniejszym opracowaniu.

\subsection{System Eugen Langen}

Poczatek kolei jednoszynowych datowany jest na lata dwudzieste dziewiętnastego wieku, ale prawdziwy przełom nastapił dopiero w 1901 roku, kiedy oddano do użytku linię kolei podwieszanej łączącej dwa niemieckie miasta: Erbelfeld i Barmen. W 1929 roku miasta te zostały połączone $\mathrm{i}$ wraz $\mathrm{z}$ pięcioma innymi mniejszymi miejscowościami, dały początek jednemu miastu Wuppertal, leżącemu dziś w niemieckim kraju związkowym Nadrenia Północna Westfalia.

Kursująca już od wielu lat jednoszynowa kolej podwieszana projektu Eugena Langena stała się tym samym pierwszym na świecie miejskim środkiem transportu tego typu. Kolej ta, potocznie nazywana Schwebebahn (z niem. kolej podwieszana), z powodzeniem kursuje do dnia dzisiejszego, stanowiąc unikalny w skali światowej system.

W tym długim okresie czasu doszło wyłącznie do jednego poważnego wypadku (5 ofiar śmiertelnych i 47 rannych), którego przyczyną było pozostawienie przez serwisanta narzędzi na torze. Statystyka ta świadczy o wysokim bezpieczeństwie kolei podwieszanej [3].

W systemie tym pudło pojazdu zostało podwieszone asymetrycznie pod torem, a wózki wyposażono w dwa stalowe koła z podwójnym obrzeżem, które uniemożliwiają ich zejście z szyny, czyli wykolejenie. Podwieuniemożliwiają ich zejście z szyny, czyli wykolejenie. Podwieszenie asymetryczne nie zapewnia pełnej stabilności jazdy, a pojazd wykonuje pewien ruch wahadłowy względem swojego punktu podparcia. W 
Table 1 Technical specification of Wuppertal suspended railway

Tabela 1 Wybrane dane kolei podwieszanej w Wuppertal

\begin{tabular}{|c|c|c|}
\hline Feature / Cecha & $\begin{array}{c}\text { Unit / } \\
\text { Jednostka }\end{array}$ & $\begin{array}{l}\text { Value / } \\
\text { Wartość }\end{array}$ \\
\hline Line length / Długość trasy & $\mathrm{km}$ & 13,3 \\
\hline $\begin{array}{l}\text { Passengers per weekday / Średnia } \\
\text { dzienna liczba pasażerów }\end{array}$ & - & 65479 \\
\hline $\begin{array}{l}\text { Largest incline / Maksymalne } \\
\text { nachylenie toru }\end{array}$ & $\%$ & 3,02 \\
\hline Stops / Liczba stacji & - & 20 \\
\hline $\begin{array}{l}\text { Average transit speed / Średnia } \\
\text { prędkość eksploatacyjna }\end{array}$ & $\mathrm{km} / \mathrm{h}$ & 27,5 \\
\hline \multicolumn{3}{|c|}{$\begin{array}{l}\text { Technical data of the 15th generation vehicles } \\
\text { Dane techniczne pojazdów } 15 \text {. generacji }\end{array}$} \\
\hline Overall length / Długość całkowita & $\mathrm{mm}$ & 24060 \\
\hline Width / Szerokość & $\mathrm{mm}$ & 2200 \\
\hline Height / Wysokość & $\mathrm{mm}$ & 2750 \\
\hline $\begin{array}{l}\text { Empty vehicle mass / Masa własna } \\
\text { pojazdu }\end{array}$ & $\mathrm{kg}$ & 23408 \\
\hline $\begin{array}{l}\text { Total vehicle mass / Dopuszczalna } \\
\text { masa całkowita }\end{array}$ & $\mathrm{kg}$ & 38260 \\
\hline $\begin{array}{l}\text { Total capacity / Całkowita liczba } \\
\text { miejsc }\end{array}$ & - & 175 \\
\hline $\begin{array}{l}\text { Seating capacity / Liczba miejsc } \\
\text { siedzących }\end{array}$ & - & 45 \\
\hline $\begin{array}{l}\text { Standing capacity / Liczba miejsc } \\
\text { stojących }\end{array}$ & - & 130 \\
\hline $\begin{array}{l}\text { Power supply voltage DC / } \\
\text { Napięcie zasilania DC }\end{array}$ & $\mathrm{V}$ & 750 \\
\hline $\begin{array}{l}\text { Total vehicle power / Moc } \\
\text { całkowita }\end{array}$ & $\mathrm{kW}$ & 300 \\
\hline $\begin{array}{l}\text { Maximum speed / Prędkość } \\
\text { maksymalna }\end{array}$ & $\mathrm{km} / \mathrm{h}$ & 60 \\
\hline $\begin{array}{l}\text { Maximum acceleration / } \\
\text { Przyspieszenie maksymalne }\end{array}$ & $\mathrm{m} / \mathrm{s}^{2}$ & 1,2 \\
\hline $\begin{array}{l}\text { Maximum braking deceleration / } \\
\text { Opóźnienie maksymalne }\end{array}$ & $\mathrm{m} / \mathrm{s}^{2}$ & 2,3 \\
\hline Axle arrangement / Układ osi & - & $\mathrm{B}^{6} \mathrm{~B}^{6}+\mathrm{B}^{\circ} \mathrm{B}^{6}$ \\
\hline $\begin{array}{l}\text { New wheel diameter / Średnica kół } \\
\text { nowych }\end{array}$ & $\mathrm{mm}$ & $800 / 784$ \\
\hline $\begin{array}{l}\text { Bogie centre distance / Rozstaw } \\
\text { środków wózków }\end{array}$ & $\mathrm{mm}$ & 7645 \\
\hline Wheelbase / Baza wózka & $\mathrm{mm}$ & 1280 \\
\hline
\end{tabular}

This three-section, unidirectional, multiple-unit controlled vehicle is suspended under four powered bogies (two per outermost sections), which are controlled by two traction inverters (one per section). These inverters convert direct current to alternating current which properties, such as frequency and voltage, can be modified. One asynchronous motor simultaneously powers both wheels in the bogie and subsequently driving torque is transmitted via two-stage, helicalbevel reduction gear unit to a hollow output shaft, which is connected with wheel axle by rubber wedge coupling (Fig. 2).

Two different service brakes are used in the vehicle: electrodynamic brake and passive electro-hydraulic brake. The first one's brake force is produced by traction motor which works like generator, so this is vehicle basic brake system mainly thanks to the fact that all wheels are powered. The second one's brake force is generated by springs, so it's used also as a parking normalnej eksploatacji kąty te nie przyjmują znacznych wartości, których górną, dopuszczalną granicę stanowi $15^{\circ}$. Dwie szyny (linia w Wuppertal jest dwukierunkowa) są zamocowane, w odległości 4 metrów od siebie, do stalowych kratownic rozpiętych pomiędzy 464 dźwigarami (z wyłączeniem zajezdni). Zmianę toru po którym porusza się skład umożliwiają przesuwnice lub obrotnice.

Aktualnie linię obsługuje 31 pojazdów 15. generacji, produkcji Vossloh Kiepe (rys. 1), których wybrane dane techniczne, opracowane według [3, 4], zostały zestawione w tabeli 1 [3].

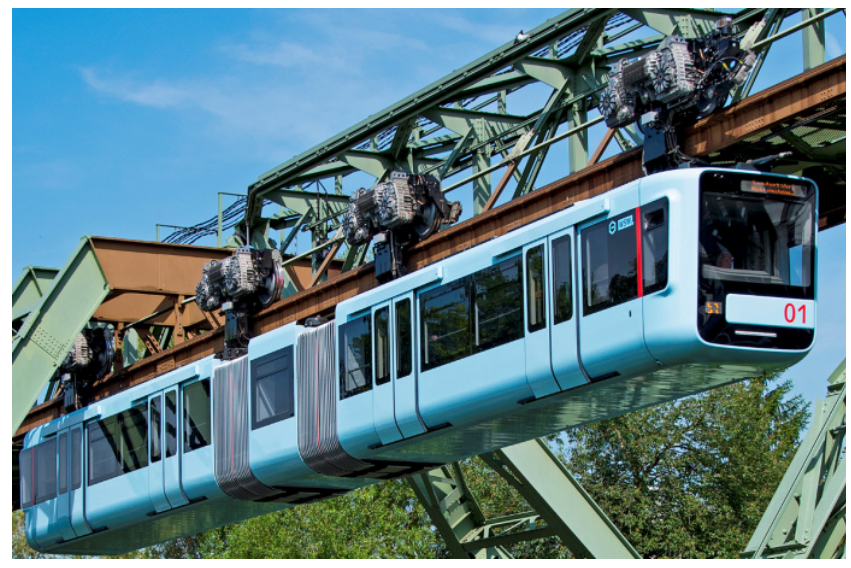

Fig. 1. Vehicle of Eugen Langen system - G 15 [2]

Rys. 1. Pojazd systemu Eugen Langen - G 15 [2]

Ten trójczłonowy, jednokierunkowy, przystosowany do trakcji wielokrotnej pojazd został zawieszony na czterech wózkach napędnych (po dwa na każdy $\mathrm{z}$ członów skrajnych) sterowanych poprzez dwa falowniki trakcyjne (po jednym na człon), zamieniające doprowadzony do pojazdu dodatkową szyną prąd stały na zmienny o nastawialnych parametrach (takich jak napięcie, częstotliwość). W wózkach zastosowano napęd grupowy, to jest centralnie umieszczony silnik asynchroniczny napędza jednocześnie oba koła. Moment napędowy przenoszony jest przez dwustopniowa, stożkowo-walcową mechaniczną przekładnię redukcyjną, której drążony wał wyjściowy połączony jest z osią koła za pośrednictwem sprzęgła z pakietami elementów metalowo-gumowych (rys. 2). Wymagana podatność pomiędzy wózkiem, a pudłem została uzyskana przy jego mocowaniu do dźwigara podwieszenia.

W pojeździe wykorzystano dwa rodzaje hamulców: hamulec elektrodynamiczny oraz pasywny hamulec elektrohydrauliczny. Pierwszy z nich wytwarza siłe hamowania na skutek prądnicowej pracy silników trakcyjnych, a więc przy występowaniu wszystkich osi napędnych, stanowi on podstawowy typ hamulca. $Z$ kolei w pasywnym hamulcu elektrohydraulicznym siłę hamowania wytwarza zespół sprężyn, a więc pełni on również funkcję hamulca postojowego. Zaciski hamulcowe znajdują się jedynie na tylnych osiach poszczególnych wózków, a ich okładziny cierne dociskane są do zewnętrznych powierzchni bocznych 


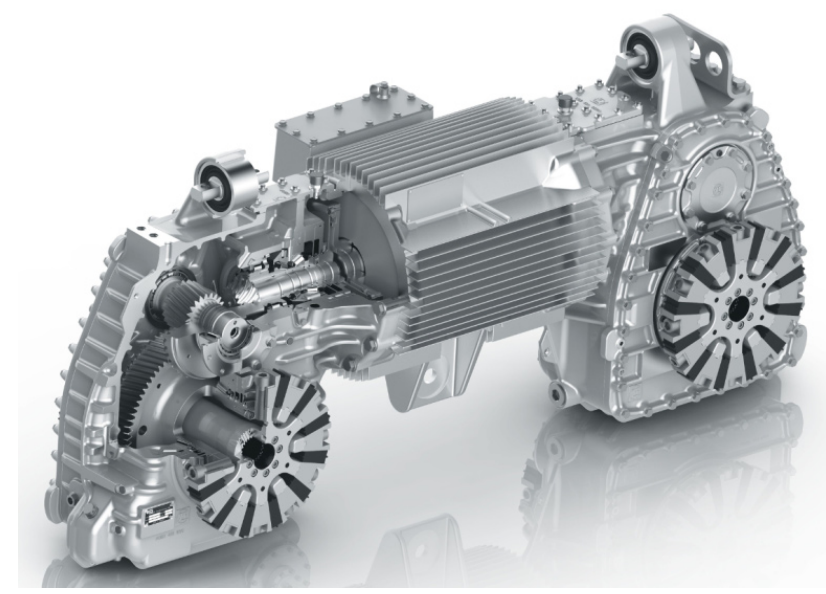

Fig. 2. Propulsion system of G 15 vehicle [5] Rys. 2. Układ napędowy pojazdu G 15 [5]

brake. Brake units are mounted only on the bogies rear wheels and their brake linings clamp on the exterior sides of the wheel flanges. Furthermore, vehicle bogies aren't equipped in track brake (brake force is independent from wheel-rail adhesion conditions) or sanding system which enables a temporary adhesion coefficient increase [6].

Asymmetrical suspension and one-rail system is a source of intensive contact between wheel flange and rail (not only in a curved track), so it's source of noise emission and both elements wear increase. To prevent such phenomena, bogies are equipped with wheel flange lubrication system - SKF EasyRail Airless [2].

\subsection{SAFEGE system}

This system was invented in 1958 by SAFEGE consortium of several French companies which had been working at one line extension of Paris underground railway system. Nevertheless, that system was firstly used in Japanese Kanagawa prefecture, where almost seven kilometres long, unidirectional line (Shonan Monorail) passes through two cities: Kamakura and Fujisawa. Two tunnels, overall length of $656 \mathrm{~m}$, are lined on this short route [7].

In SAFEGE system, the car body is symmetrically suspended under the one-side open, box-shaped guideway beam inside which bogies with rubber tyres run. The Shonan monorail line rolling stock fleet contains seven, three-car-body trains series 5000 manufactured by Mitsubishi (Fig. 3) and their technical data according to [7] is presented in Table 2. The second one SAFEGE monorail is located in Japan city Chiba and it was opened in 1988 [10]. This particular system is the world's longest suspended monorail system and it contains two double-track lines.

At the moment, Chiba monorail line is equipped with new rolling stock fleet. Technical data according to $[10,11]$ of new three-section vehicles (Fig. 4) is presented in Table 3. obrzeży kół. Ponadto w wózkach pojazdu nie zastosowano hamulca szynowego (siła hamowania niezależna od sił przyczepności) czy piasecznic, pozwalających na chwilowe zwiększenie współczynnika przyczepności [6].

Ze względu na asymetryczne podwieszenie oraz wykorzystanie pojedynczej szyny, stosunkowo często dochodzi do kontaktu obrzeża z szyną (nie tylko w czasie jazdy w łuku torowym), co wpływa na zwiększenie emisji dźwięku i zużycia obu elementów. W celu przeciwdziałania tym negatywnym zjawiskom zastosowano elektromagnetyczny system smarowania obrzeży kół - SKF EasyRail Airless [2].

\subsection{System SAFEGE}

System ten został opracowany już w 1958 roku przez francuskie konsorcjum firm SAFEGE, powołane $w$ celu zaprojektowania przedłużenia jednej z linii paryskiego metra. Jednak zastosowanie znalazł on dopiero w 1970 roku w japońskiej prefekturze Kanagawa, gdzie niespełna siedmiokilometrowa, jednotorowa linia (Shonan Monorail) przebiega przez teren dwóch miast: Kamakura i Fujisawa. Na tej krótkiej trasie wybudowano dwa tunele o łącznej długości $656 \mathrm{~m}$ [7]. W systemie SAFEGE pudło pojazdu podwieszone jest symetrycznie pod torem, a wózki wyposażone w ogumione koła poruszają się wewnątrz otwartej od strony gruntu belki jezdnej. Linię Shonan Monorail obsługuje flota siedmiu trójwagonowych składów serii 5000 produkcji firmy Mitsubishi (rys. 3), których wybrane dane techniczne, opracowane w oparciu o [7], zostały zestawione w tabeli 2 .

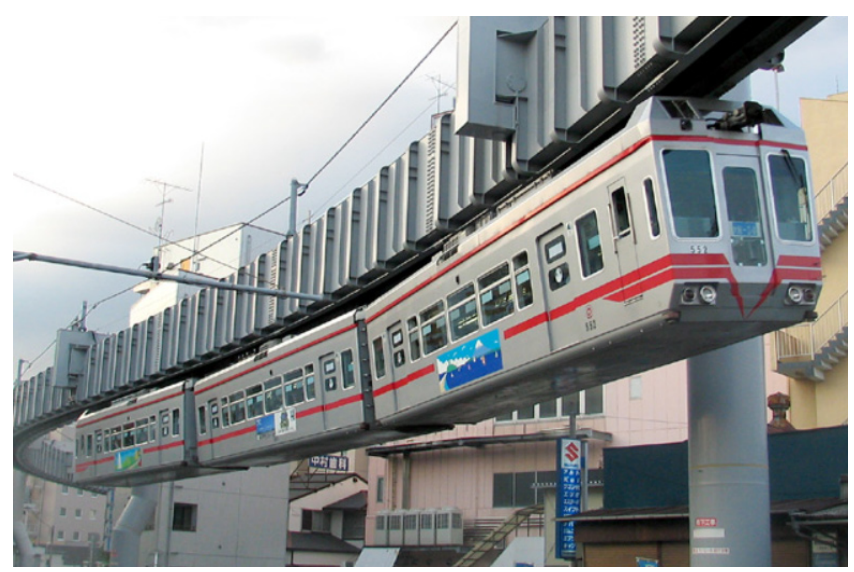

Fig. 3. Vehicle on Shonan Monorail line [8] Rys. 3. Pojazd na linii Shonan Monorail [8]

Druga kolej podwieszana systemu SAFEGE znajduje się w japońskim mieście Chiba i została oddana do użytku w 1988 roku [10]. Jest to najdłuższy system podwieszanej kolei jednoszynowej na świecie, w którego skład wchodzą dwie dwutorowe linie.

Aktualnie trwa wymiana taboru obsługującego Chiba Monorail, a wybrane dane techniczne nowych dwuczłonowych pojazdów (rys. 4) zostały zestawione w tabeli 3, opracowanej na podstawie [10,11]. 
Table 2 Technical specification of Shonan monorail Tabela 2 Wybrane dane kolei Shonan monorail

\begin{tabular}{|c|c|c|}
\hline Feature / Cecha & $\begin{array}{c}\text { Unit / } \\
\text { Jednostka }\end{array}$ & $\begin{array}{l}\text { Value / } \\
\text { Wartość }\end{array}$ \\
\hline Line length / Długość trasy & $\mathrm{km}$ & 6,6 \\
\hline $\begin{array}{l}\text { Passengers per weekday / Średnia } \\
\text { dzienna liczba pasażerów }\end{array}$ & - & 30588 \\
\hline $\begin{array}{l}\text { Largest incline / Maksymalne na- } \\
\text { chylenie toru }\end{array}$ & $\%$ & 7,4 \\
\hline Stops / Liczba stacji & - & 8 \\
\hline $\begin{array}{l}\text { Average transit speed / Średnia } \\
\text { prędkość eksploatacyjna }\end{array}$ & $\mathrm{km} / \mathrm{h}$ & 28,8 \\
\hline \multicolumn{3}{|c|}{$\begin{array}{l}\text { Technical data of the Mitsubishi series } 5000 \text { vehicles ( } 3 \text { cars) } \\
\text { Dane techniczne pojazdów Mitsubishi serii } 5000 \text { (3 wagony) }\end{array}$} \\
\hline Overall length / Długość całkowita & $\mathrm{mm}$ & 38250 \\
\hline Width / Szerokość & $\mathrm{mm}$ & 2650 \\
\hline Height / Wysokość & $\mathrm{mm}$ & 3094 \\
\hline $\begin{array}{l}\text { Empty vehicle mass / Masa własna } \\
\text { pojazdu }\end{array}$ & $\mathrm{kg}$ & 51800 \\
\hline $\begin{array}{l}\text { Nominal capacity / Nominalna } \\
\text { liczba miejsc }\end{array}$ & - & 228 \\
\hline $\begin{array}{l}\text { Crush capacity / Maksymalna licz- } \\
\text { ba miejsc }\end{array}$ & - & 464 \\
\hline $\begin{array}{l}\text { Power supply voltage DC / Napię- } \\
\text { cie zasilania DC }\end{array}$ & $\mathrm{V}$ & 1500 \\
\hline $\begin{array}{l}\text { Total vehicle power / Moc całkowi- } \\
\text { ta }\end{array}$ & $\mathrm{kW}$ & 660 \\
\hline $\begin{array}{l}\text { Maximum speed / Prędkość mak- } \\
\text { symalna }\end{array}$ & $\mathrm{km} / \mathrm{h}$ & 75 \\
\hline $\begin{array}{l}\text { Maximum acceleration / Przyspie- } \\
\text { szenie maksymalne }\end{array}$ & $\mathrm{m} / \mathrm{s}^{2}$ & 1,12 \\
\hline $\begin{array}{l}\text { Maximum braking deceleration / } \\
\text { Opóźnienie maksymalne }\end{array}$ & $\mathrm{m} / \mathrm{s}^{2}$ & 1,26 \\
\hline $\begin{array}{l}\text { Bogie centre distance / Rozstaw } \\
\text { środków wózków }\end{array}$ & $\mathrm{mm}$ & 7650 \\
\hline Wheelbase / Baza wózka & $\mathrm{mm}$ & 1500 \\
\hline
\end{tabular}

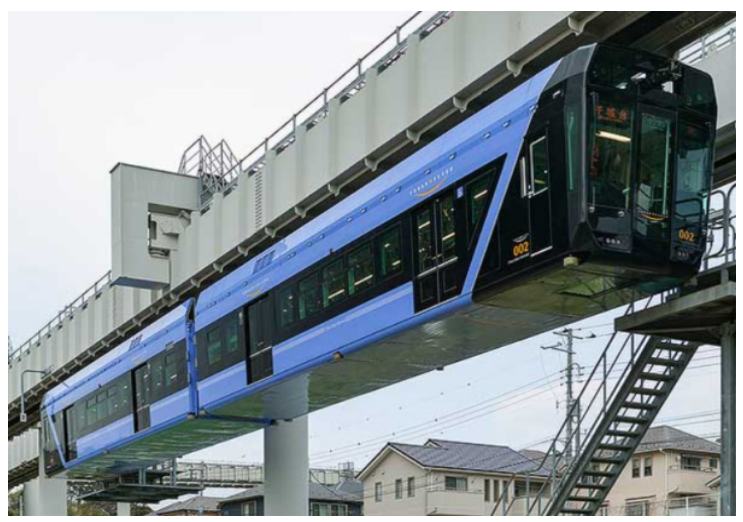

Fig. 4. Vehicle on Chiba Urban Monorail Line [9] Rys. 4. Pojazd na linii Chiba Urban Monorail [9]

A typical SAFEGE system bogie (Fig. 5) uses two different types of wheels: driving and guiding. Tractive force and vehicle weight are transmitted by the first one. The second one is used to maintain appropriate vehicle motion trajectory by rolling on the side walls of the guide beam. Both types of wheels are filled with air or nitrogen at a pressure of: $880 \mathrm{kPa}$ for driving wheels and $980 \mathrm{kPa}$ for guiding wheels [12]. Every car body is suspended under two bogies by trapezoidal link with oil damper. Furthermore, car body is made of aluminium which ensures weight reduction. [7]
Table 3 Technical specification of Chiba Urban monorail Tabela 3 Wybrane dane kolei Chiba Urban monorail

\begin{tabular}{|l|c|c|}
\hline Feature / Cecha & $\begin{array}{c}\text { Unit / } \\
\text { Jednostka }\end{array}$ & $\begin{array}{c}\text { Value / } \\
\text { Wartość }\end{array}$ \\
\hline Line length / Długość trasy & $\mathrm{km}$ & 15,2 \\
\hline $\begin{array}{l}\text { Passengers per weekday / Średnia } \\
\text { dzienna liczba pasażerów }\end{array}$ & - & 44000 \\
\hline $\begin{array}{l}\text { Largest incline / Maksymalne na- } \\
\text { chylenie toru }\end{array}$ & $\%$ & 6 \\
\hline Stops / Liczba stacji & - & 18 \\
\hline $\begin{array}{l}\text { Average transit speed / Średnia } \\
\text { predkość eksploatacyjna }\end{array}$ & $\mathrm{km} / \mathrm{h}$ & 30 \\
\hline
\end{tabular}

prędkość eksploatacyjna

Technical data of the Mitsubishi urban flyer type $0 /$

Dane techniczne pojazdów Mitsubishi urban flyer type 0

\begin{tabular}{|l|c|c|}
\hline Overall length / Długość całkowita & $\mathrm{mm}$ & 30800 \\
\hline Width / Szerokość & $\mathrm{mm}$ & 2580 \\
\hline $\begin{array}{l}\text { Empty / Wysokićśc mass / Masa własna } \\
\text { pojazdu }\end{array}$ & $\mathrm{mg}$ & 3715 \\
\hline $\begin{array}{l}\text { Total capacity / Całkowita liczba } \\
\text { miejsc }\end{array}$ & - & 43000 \\
\hline $\begin{array}{l}\text { Seating capacity / Liczba miejsc } \\
\text { siedzących }\end{array}$ & - & 60 \\
\hline $\begin{array}{l}\text { Power supply voltage DC / Napię- } \\
\text { cie zasilania DC }\end{array}$ & $\mathrm{V}$ & 1500 \\
\hline $\begin{array}{l}\text { Maximum speed / Prędkość mak- } \\
\text { symalna }\end{array}$ & $\mathrm{km} / \mathrm{h}$ & 65 \\
\hline $\begin{array}{l}\text { Maximum acceleration / Przyspie- } \\
\text { szenie maksymalne }\end{array}$ & $\mathrm{m} / \mathrm{s}^{2}$ & 0,98 \\
\hline $\begin{array}{l}\text { Maximum braking deceleration / } \\
\text { Opóźnienie maksymalne }\end{array}$ & $\mathrm{m} / \mathrm{s}^{2}$ & 1,26 \\
\hline $\begin{array}{l}\text { Maximum braking deceleration / } \\
\text { Rozstaw środków wózków }\end{array}$ & $\mathrm{mm}$ & 7650 \\
\hline Wheelbase / Baza wózka & $\mathrm{mm}$ & 1500 \\
\hline
\end{tabular}

Typowy dla systemu SAFEGE wózek (rys. 5) wyposażony jest dwie pary kó jezdnych i prowadzących. Zadaniem pierwszych $\mathrm{z}$ nich jest przenoszenie sił trakcyjnych oraz utrzymanie masy pojazdu. Natomiast koła prowadzące służą nadaniu mu odpowiedniego kierunku ruchu, poprzez współpracę z bocznymi ścianami belki jezdnej. Oba rodzaje kół wypełnione są powietrzem lub azotem o ciśnieniu równym odpowiednio $880 \mathrm{kPa}$ i $980 \mathrm{kPa}$ [12]. Każdy wagon lub człon podwieszony jest do pary tego typu wózków przy pomocy zawieszenia trapezowego $\mathrm{z}$ thumikami hydraulicznymi. Samo pudło wagonu, dla zachowania niskiej masy własnej, stanowi konstrukcję aluminiową [7].

Zasilanie elektryczne doprowadzone jest do pojazdu za pośrednictwem szyny prądowej, a sieć powrotną realizuje para dodatkowych szyn, całość zamocowana jest wewnątrz belki jezdnej (rys. 6). Belkę tę stanowi stalowa konstrukcja spawana w kształcie odwróconej litery $\mathrm{U}, \mathrm{z}$ równomiernie rozmieszczonymi żebrami wzmacniającymi. Powierzchnię torów jezdnych pokrywa się zaprawą epoksydową oraz drewnem. Poszczególne odcinki belki podwieszone są pod stalowymi kolumnami, standardowo rozmieszczonymi $\mathrm{w}$ odstępach $30 \mathrm{~m}$ (minimalnie 12,48 m, maksymalnie $36,3 \mathrm{~m}$ ). Kolumny te dokręcane są do betonowego fundamentu, wyposażonego $\mathrm{w}$ zbrojone filary, mogące 


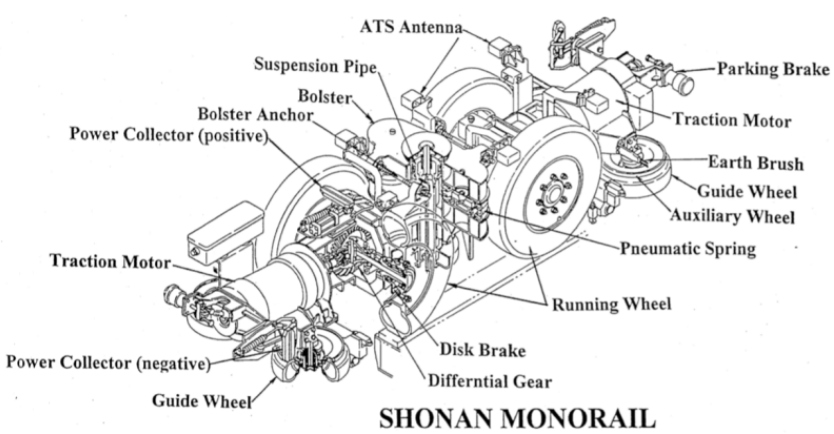

Fig. 5. Example of SAFEGE railway bogie [7]

Rys. 5. Przykładowy wózek pojazdu systemu SAFEGE [7]

Electrical power is supplied to the vehicle by so-called third rail and two additional rails are used to close current circuit. All of that is situated inside a guideway beam (Fig. 6). Such beam is U-shaped, welded steel construction with equidistant reinforcement ribs. The running surfaces are covered by epoxy mortar and wood. Guideway beam sections are suspended under columns at equal distances of $30 \mathrm{~m}$ (minimal 12,48 m, maximal $36,3 \mathrm{~m}$ ). Those columns are supported on concrete foundations with reinforced concrete pillars which length could be up to $12 \mathrm{~m}$. Obviously, foundation's technical data depends on soil properties [7]. Working principle of SAFEGE system switches is similar to the traditional railway but the switching time is much longer and could reach more than several seconds. Every switch is constructed from moveable partition which could become one of the guideway beams side walls.

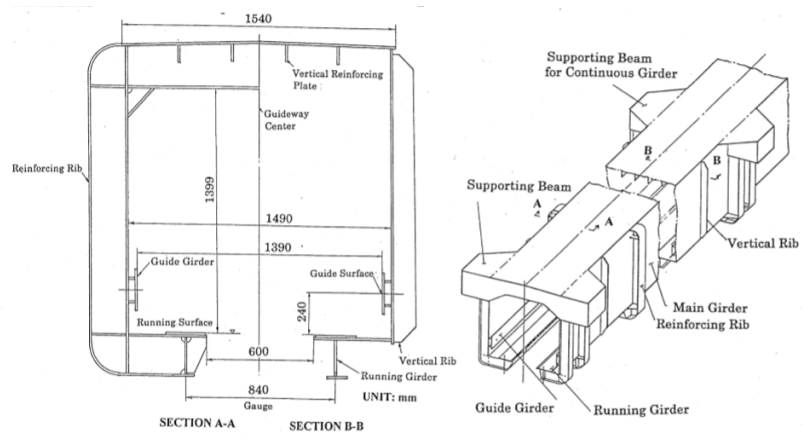

Fig. 6. Example of SAFEGE guideway girder [7]

Rys. 6. Przykładowa budowa belki jezdnej sytemu SAFEGE [7]

\subsection{Monorail systems comparison}

According to Fig. 7, which compares both systems in a simplified way; SAFEGE system has the following benefits: symmetrical suspension (higher vehicle running stability) and running surface protection from weather conditions (stable value of adhesion coefficient).

Other differences result from steel wheel-rail contact or rubber tyre running on the surface of the guideway beam. Steel wheels, in comparison to tyres, are characterized by: sięgać aż $12 \mathrm{~m}$ pod powierzchnię gruntu. Oczywiście parametry techniczne fundamentów zależą od własności podłoża [7].

System SAFEGE wykorzystuje układy zwrotnicze o podobnej zasadzie działania, co te stosowane w kolejnictwie, ale o dłuższym czasie przełączania sięgającym kilkunastu sekund. Zbudowane są one z ruchomej przegrody, stanowiącej jedną ze ścian bocznych danej belki jezdnej.

\subsection{Analiza porównawcza obu systemów}

Rys. 7 schematycznie porównuje oba opisane wcześniej systemy. Na jego podstawie można wskazać największe zalety rozwiązania typu SAFEGE, to jest: podwieszenie symetryczne (zapewniające większą stabilność w trakcie jazdy) oraz zapewnienie całkowitej ochrony powierzchni jezdnych przed warunkami atmosferycznymi, co przekłada się na w przybliżeniu stałą wartość współczynnika przyczepności.

Pozostałe różnice wynikają z zastosowania stalowych kół współpracujących z szyną, lub kół ogumionych poruszających się po specjalnych powierzchniach jezdnych. Pierwsze z wymienionych cechują się:

- mniejszymi oporami ruchu

- większą nośnością (rzeczywiste ograniczenie nacisku osi na tor stanowi wytrzymałość infrastruktury)

- mniejszym zużyciem

- możliwością realizacji sieci powrotnej

- większą emisją dźwięku i drgań

- niższym współczynnikiem przyczepności (wpływającym na własności dynamiczne pojazdu, w rzeczywistości ograniczone komfortem pasażerów)

- pokonywaniem toru o mniejszym kącie nachylenia.

Ponadto konstrukcja wózka wyposażonego w ogumione koła jest bardziej skomplikowana, co wynika $\mathrm{z}$ konieczności zabudowy dodatkowych kół prowadzących.

\section{PROPONOWANE ROZWIAZANIE}

W przyjętym rozwiązaniu (rys. 8) zdecydowano się na pewnego rodzaju syntezę dotychczas omawianych systemów i tak pojazd został podwieszony symetrycznie pod wózkami, które poruszają się po stalowych szynach w zamkniętej belce jezdnej. W ten sposób połączono zalety systemu SAFEGE i kół kolejowych.

$Z$ racji podwieszenia symetrycznego zmiana toru ruchu pojazdu odbywa się z wykorzystaniem przesuwnic czy obrotnic. Przesuwnica tego typu może składać się z podwójnej belki jezdnej, w której znajdują się tory o przeciwnych promieniach krzywizny.

Do najważniejszych założeń projektowych należy zaliczyć: pokonywanie toru o znacznym kącie nachylenia, osiaganie prędkości maksymalnej przekraczającej $50 \mathrm{~km} / \mathrm{h}$ oraz zapewnienie możliwie dużej pojem- 


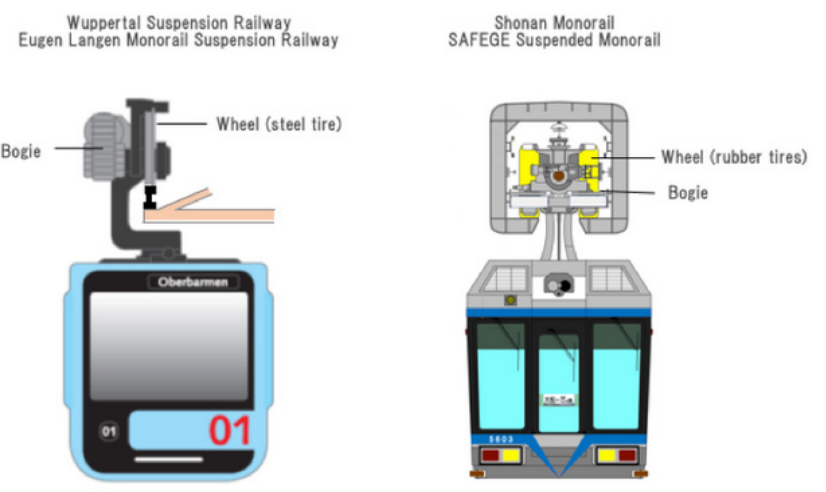

Fig. 7. Comparison of existing suspended railway systems [13] Rys. 7. Porównanie istniejących systemów kolei podwieszanej [13]

- lower running resistance;

- higher load capacity (pressure of a wheelset on the track is limited by the guideway beam strength);

- less wear;

- possibility of current return circuit implementation;

- higher noise and vibration emission;

- lower adhesion coefficient (which determine vehicle dynamic properties that are limited by passengers comfort);

- less ability to run on a track with a steep gradient Furthermore, rubber-tyres bogies are much more complicated, thanks to necessity of mounting additional guide wheels.

\section{PROPOSED SOLUTION}

The solution proposed by the authors (Fig. 8) is based on a synthesis of the two aforementioned systems so the vehicle is symmetrically suspended under the bogies which are running on steel rails inside the guideway beam. This way, the advantages of steel wheels and SAFEGE system were combined.

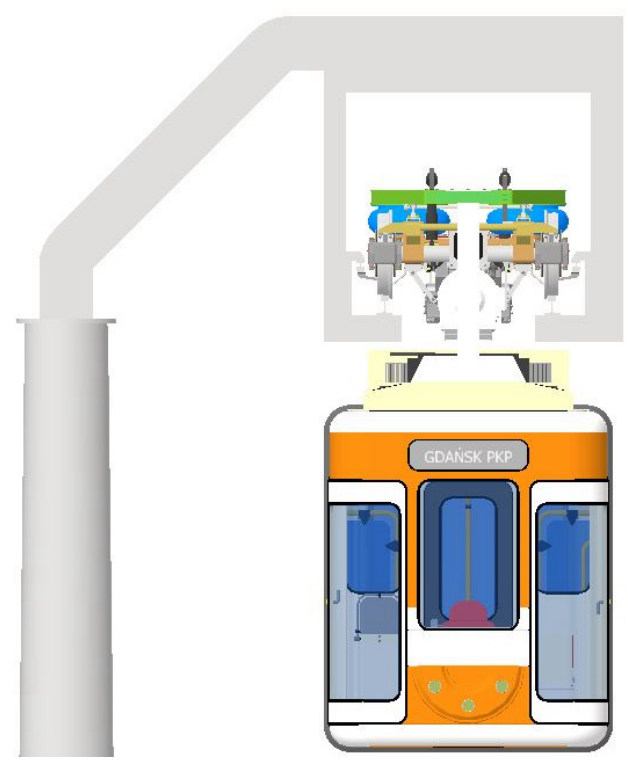

Fig. 8. Concept of the suspended railway system [14] Rys. 8. Proponowany system kolei podwieszanej [14] ności. Dodatkowo miejskie przeznaczenie pojazdu wymusza pokonywanie łuków torowych o małym promieniu krzywizny oraz ograniczenie poziomu natężenia dźwięku emitowanego do otoczenia. Dobre wpisywanie się pojazdu w łuki torowe zapewnia chociażby trójczłonowa konstrukcja (rys. 9).

Teoretycznie możliwe do uzyskania w rzeczywistej konstrukcji, wybrane parametry techniczne pojazdu zostały zestawione w tabeli 4 [14].

Table 4 Technical specification of suspended EMU Tabela 4 Wybrane dane techniczne podwieszanego EZT

\begin{tabular}{|l|c|c|}
\hline Feature / Cecha & $\begin{array}{c}\text { Unit / } \\
\text { Jednostka }\end{array}$ & $\begin{array}{c}\text { Value / War- } \\
\text { tość }\end{array}$ \\
\hline $\begin{array}{l}\text { Overall length / Długość cał- } \\
\text { kowita }\end{array}$ & $\mathrm{mm}$ & 32580 \\
\hline $\begin{array}{l}\text { Width of the vehicle car body / } \\
\text { Szerokość pudła wagonu }\end{array}$ & $\mathrm{mm}$ & 2500 \\
\hline $\begin{array}{l}\text { Height of the vehicle car body / } \\
\text { Wysokość pudła wagonu }\end{array}$ & $\mathrm{mm}$ & 3025 \\
\hline $\begin{array}{l}\text { Empty vehicle mass / Masa } \\
\text { własna pojazdu }\end{array}$ & $\mathrm{kg}$ & 43611 \\
\hline $\begin{array}{l}\text { Maximum vehicle mass / Do- } \\
\text { puszczalna masa całkowita }\end{array}$ & $\mathrm{kg}$ & 71811 \\
\hline $\begin{array}{l}\text { Total capacity / Całkowita } \\
\text { liczba miejsc }\end{array}$ & - & 376 \\
\hline $\begin{array}{l}\text { Seating capacity / Liczba miejsc } \\
\text { siedzących }\end{array}$ & - & 80 \\
\hline $\begin{array}{l}\text { Standing capacity / Liczba } \\
\text { miejsc stojących }\end{array}$ & - & 296 \\
\hline $\begin{array}{l}\text { Power supply voltage DC / } \\
\text { Napięcie zasilania DC }\end{array}$ & $\mathrm{V}$ & 600 \\
\hline $\begin{array}{l}\text { Total vehicle power / Moc } \\
\text { całkowita }\end{array}$ & $\mathrm{kW}$ & 840 \\
\hline $\begin{array}{l}\text { Maximum speed / Prędkość } \\
\text { maksymalna }\end{array}$ & $\mathrm{km} / \mathrm{h}$ & 70 \\
\hline $\begin{array}{l}\text { Starting acceleration / Przyspie- } \\
\text { szenie pocz. rozruchu }\end{array}$ & $\mathrm{m} / \mathrm{s}^{2}$ & 1,30 \\
\hline $\begin{array}{l}\text { Ending acceleration / Przyspie- } \\
\text { szenie końca rozruchu }\end{array}$ & $\mathrm{m} / \mathrm{s}^{2}$ & 0,45 \\
\hline $\begin{array}{l}\text { Maximum braking deceleration } \\
\text { / Opóźnienie hamowania maks. }\end{array}$ & $\mathrm{m} / \mathrm{s}^{2}$ & 3,60 \\
\hline Axle arrangement / Układ osi & - & $1 \mathrm{~A}^{\prime}+1 \mathrm{~A}{ }^{\prime}+1 \mathrm{~A}^{\prime}$ \\
\hline Wheel diameter / Średnica kół & $\mathrm{mm}$ & $700 / 750$ \\
\hline $\begin{array}{l}\text { Bogie centre distance / Rozstaw } \\
\text { czopów skrętu }\end{array}$ & $\mathrm{mm}$ & 10680 \\
\hline Wheelbase / Baza wózka & $\mathrm{mm}$ & 1600 \\
\hline
\end{tabular}

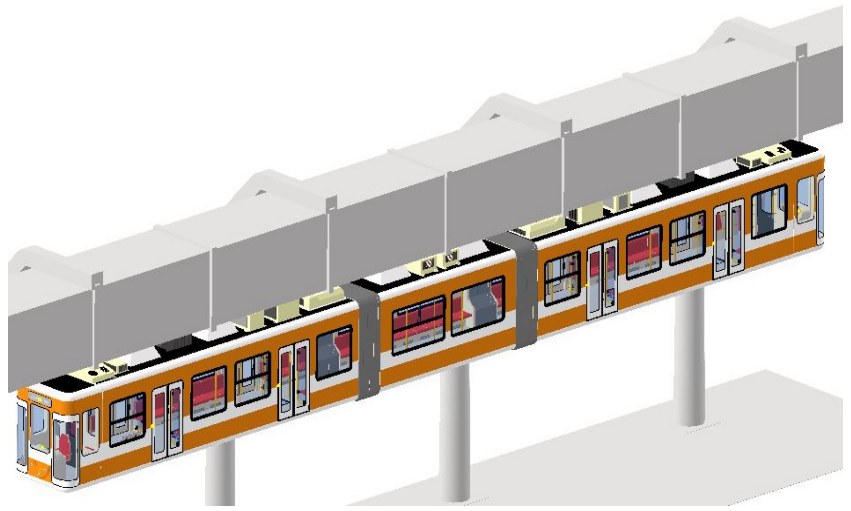

Fig. 9. View of proposed suspended railway vehicle [14] Rys. 9. Widok ogólny pojazdu kolei podwieszanej [14] 
Transfer- or turn- tables are used for track switching, because of a symmetrical vehicle suspension. Such type of a transfer table could consist of a double guideway beam with tracks curved in opposite direction.

The vehicle's ability to run on a significant inclination or in a curve with a small turning radius and maximal operational speed higher than $50 \mathrm{~km} / \mathrm{h}$ are the main project assumptions. Moreover, urban destination of the vehicle requires its high capacity and low noise level emission. Mentioned good running performance in a curved track is obtained by the use of threesection vehicle construction (Fig. 9).

Theoretically possible to obtain in a real construction, vehicle technical data is presented in Table 4 [14].

Comparison between the rolling stock technical specification presented in tables $1-3$ and proposed vehicle shows that the last one is comparable with existing ones and it's characterized by high: capacity, total power and maximal speed with good dynamic properties.

\subsection{Car body}

The rolling stock consists of two end sections A (Fig. 10) and one intermediate section B (Fig. 11). A particular section is suspended under one bogie. Passenger area of both sections, which interior side walls are covered by plastic panels, is equipped with several quadruple metro seats, handrails and handles. Interior floor is made of lightweight aluminium panels with two aluminium cover sheets and a corrugated core. These panels are supported by equidistant I-beams. Additionally, section A interior has got divided space adapted for needs of passengers with reduced mobility and for parents with children. Moreover, this section was equipped with two pairs of double leaf sliding plug exterior doors (one pair on each side of the car body).

On the roof of the car body A are mounted (in order from the driver's cab): the driver's cab HVAC unit, a pair of braking resistors, a static converter, a screw compressor unit, a traction inverter, a passenger HVAC unit. On the roof of car body B is mounted a pair of vehicle storage units (battery of supercapacitors).

At one end of the car body A is located the driver's cab (Fig. 12), which is separated from the passenger area by a partition wall with a pair of windows. This cabin is equipped with: driver's panel, driver seat, foldable table and additionally foldable seat. At both ends of the vehicle are mounted two pairs of glazed doors which provide good visibility and they could be used as an emergency exit. In such case, passengers are evacuated by foldable walkway to another rolling stock or to ground level via special chute.
Porównując powyższe dane $\mathrm{z}$ tabelami $1 \div 3$ można stwierdzić, iż uzyskane parametry są porównywalne do istniejących rozwiązań, a na ich tle pojazd wyróżnia się wysoką: pojemnością, mocą całkowitą i prędkością maksymalną, popartą dobrymi własnościami dynamicznymi.

\subsection{Pudło wagonu}

Pojedynczy skład złożony jest $\mathrm{z}$ dwóch skrajnych członów A (rys. 10) oraz znajdującego się pomiędzy nimi członu B (rys. 11), przy czym każdy z nich podwieszony jest pod pojedynczym wózkiem. Przestrzeń pasażerską obu członów, wyłożoną panelami z tworzywa sztucznego, wyposażono w czteroosobowe fotele typu metro oraz liczne uchwyty i poręcze. Podłoga została wykonana $\mathrm{z}$ paneli aluminiowych (składających się z dwóch zewnętrznych arkuszy blachy przedzielonych rdzeniem z blachy falistej), wspartych o równomiernie rozmieszczone dwuteowniki. Dodatkowo w członie A wydzielono przestrzeń przystosowaną do potrzeb osób niepełnosprawnych, czy rodziców z dziećmi. Ponadto człon ten został wyposażony w dwie pary dwuskrzydłowych drzwi odskokowo-przesuwnych (po jednej na każdą ze stron).

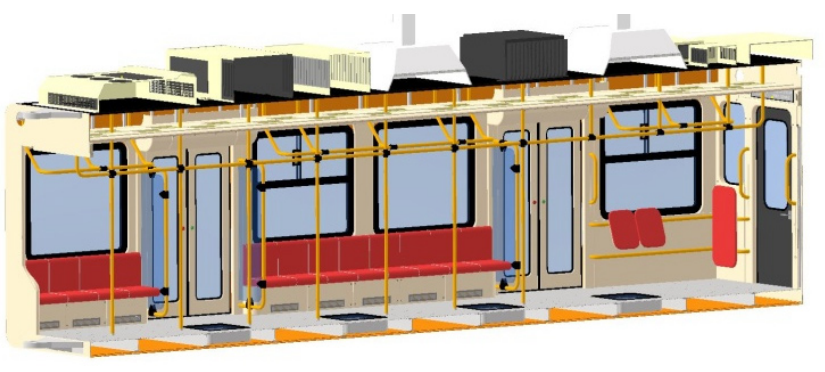

Fig. 10. Interior of the car A [14]

Rys. 10. Wnętrze członu A [14]

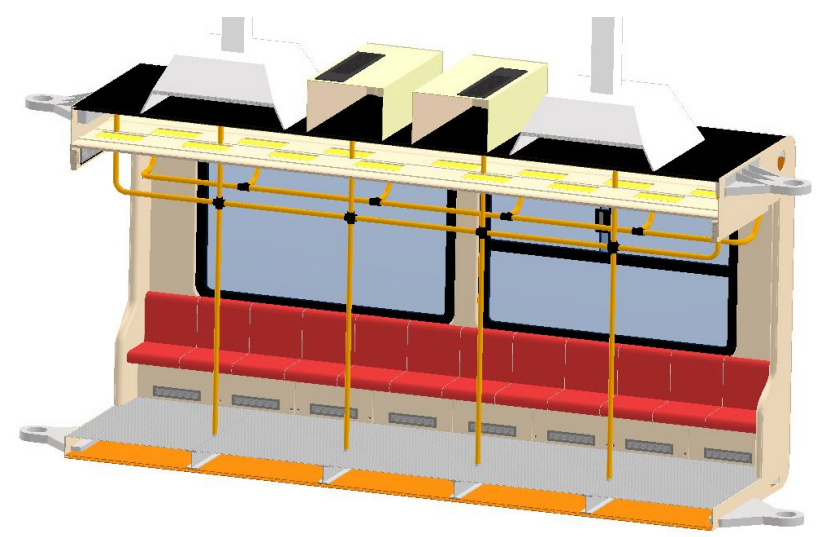

Fig. 11. Interior of the car B [14]

Rys. 11. Wnętrze członu B [14]

Na dachu członu A kolejno zamocowano (patrząc od strony czoła pojazdu): jednostkę HVAC kabiny maszynisty, parę rezystorów hamowania, przetwornicę statyczna, agregat sprężarkowy, falownik trakcyjny, jednostkę HVAC przestrzeni pasażerskiej. Z kolei na dachu członu B znajdują się dwa pojazdowe zasobniki energii (baterie superkondensatorów). 


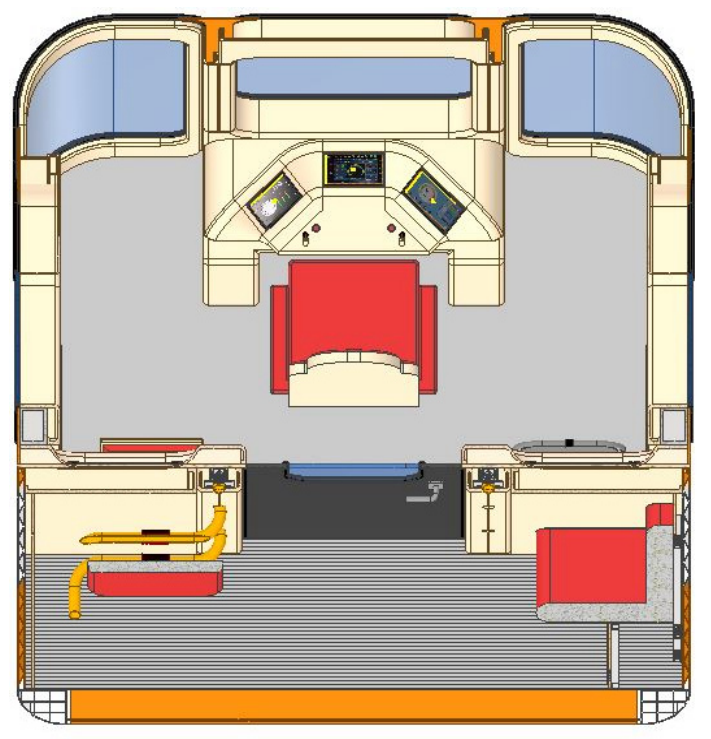

Fig. 12. Driver's cab [14]

Rys. 12. Przedział maszynisty [14]

Vehicle configuration is presented in Fig. 13, where can be seen floor's windows. Those windows are providing a possibility of the ground observation (which can make travelling more attractive) or additionally an escape way in emergency situation that is realized by pneumatic chutes.

Passenger area was relatively precisely designed to estimate surface area for standing people so their number and weight could be calculated. To do that, tramway standards from: Poland, Germany and Italy; were used, which assumptions are presented in Table 5 according to [15].

Additionally, this table contains total vehicle capacity and load (including seating passengers), which calculation was based on the aforementioned standards.

In authors' opinion the Germany norm BOStrab is the most reliable reference to real operation conditions, so vehicle load and capacity evaluation was based on it. According to that standard maximal total vehicle weight was calculated which particular element masses are presented in Table 6 [14]. Moreover, particular sections of car body weight were increased in comparison with 3D CAD model to cover devices and systems which weren't included in computer model.
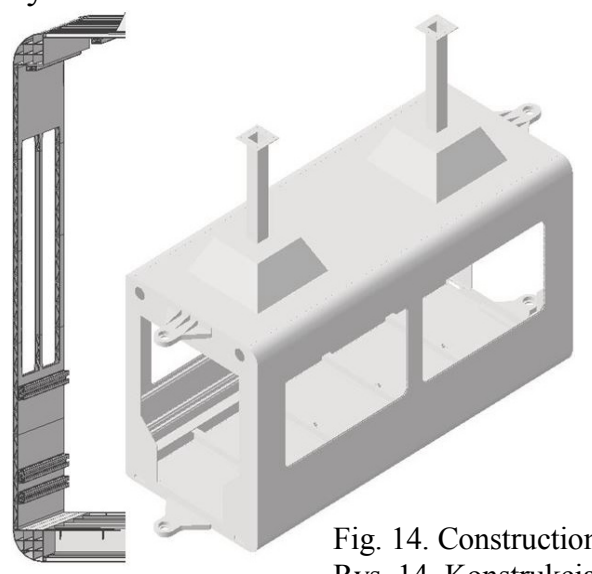

Fig. 14. Construction of the car body [14] Rys. 14. Konstrukcja pudła wagonu [14]
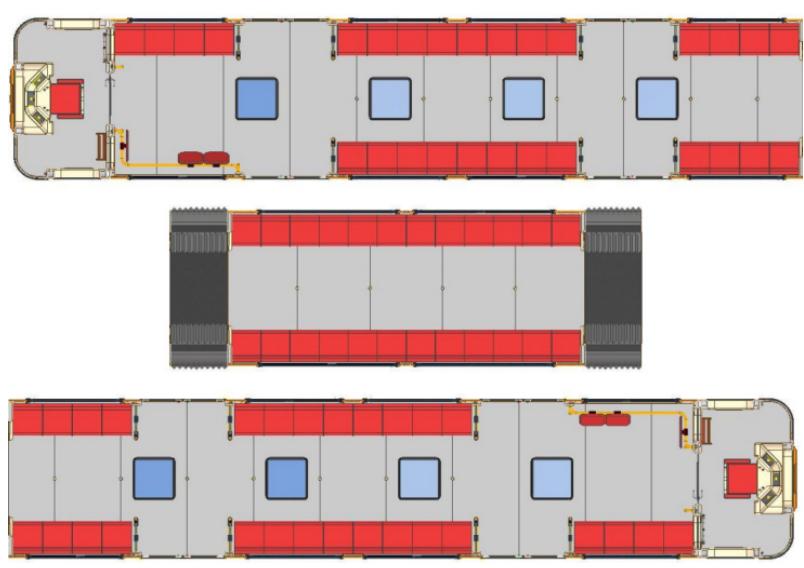

Fig. 13. Vehicle configuration [14]

Rys. 13. Konfiguracja pojazdu [14]

Człon A z jednej strony zakończony jest kabiną maszynisty (rys. 12), oddzieloną od przedziału pasażerskiego ścianką z drzwiami i parą okien. Kabinę tę wyposażono w pulpit sterowniczy, fotel maszynisty, składany stolik i dodatkowy składany fotel. Od czoła pojazdu zamontowano pare przeszklonych drzwi, zapewniających dobrą widoczność oraz stanowiących drogę ewakuacyjną. W razie konieczności opuszczenia pojazdu umożliwiają one przejście do sąsiedniego składu (po rozkładanym pomoście) lub ewakuację na poziom gruntu dzięki specjalnym zjeżdżalniom.

Na rys. 13 zaprezentowano konfigurację przestrzenną pojedynczego składu. Dobrze widoczne okna podłogowe pozwalają na obserwację otoczenia przez pasażerów (element uatrakcyjniający podróż) oraz pełnią funkcję dodatkowej drogi ewakuacyjnej, realizowanej przy użyciu zjeżdżalni pneumatycznych.

Stosunkowo dokładne zaprojektowanie przestrzeni pasażerskiej pozwoliło na oszacowanie powierzchni dostępnej dla pasażerów stojących, a więc umożliwiło określenie ich liczby i masy. W tym celu rozważono wytyczne zawarte w normach tramwajowych $\mathrm{z}$ trzech różnych państw: Polski, Niemiec i Włoch, zestawionymi w tabeli 5, a opracowanymi według [15].

Dodatkowo w tabeli tej zawarto wyliczoną na podstawie poszczególnych norm pojemność pojazdu i wynikające $\mathrm{z}$ niej obciążenie (uwzględniając pasażerów siedzących).

$\mathrm{Na}$ podstawie przytoczonych w tabeli danych zdecydowano się na określenie obciążenia i pojemności pojazdu według niemieckiej normy BOStrab, która zdaniem autorów najlepiej odpowiada warunkom rzeczywistym. Zgodnie z nią wyznaczono całkowitą masę maksymalną pojazdu, której składowe zostały zestawione w tabeli 6 [14]. Dodatkowo masy własne poszczególnych członów oraz wózków zostały zawyżone, w stosunku do wartości wynikających wprost $\mathrm{z}$ modelu CAD 3D, na poczet nieuwzględnionych instalacji i urządzeń.

Konstrukcja nośna opisanych powyżej członów została wykonana ze zgrzewanych tarciowo, ciagnionych 
Table 5 Vehicle capacity according to the tramway standards Tabela 5 Pojemność pojazdu według norm tramwajowych

\begin{tabular}{|c|c|c|c|}
\hline Feature / Cecha & $\begin{array}{l}\text { Poland } \\
\text { Polska }\end{array}$ & $\begin{array}{l}\text { Germany } \\
\text { Niemcy }\end{array}$ & $\begin{array}{c}\text { Italy } \\
\text { Włochy }\end{array}$ \\
\hline $\begin{array}{l}\text { Normal conditions / War. } \\
\text { eksploatacyjne }\left[\mathrm{m}^{2} / \mathrm{os}\right]\end{array}$ & 0,15 & 0,22 & 0,25 \\
\hline $\begin{array}{l}\text { Calculation conditions / War. } \\
\text { obliczeniowe }\left[\mathrm{m}^{2} / \mathrm{os}\right]\end{array}$ & 0,1 & 0,15 & 0,17 \\
\hline $\begin{array}{l}\text { Passenger mass }[\mathrm{kg}] / \text { Masa } \\
\text { pasażera }[\mathrm{kg}]\end{array}$ & 68 & 75 & 70 \\
\hline $\begin{array}{l}\text { Driver mass }[\mathrm{kg}] / \text { Masa } \\
\text { motorniczego }[\mathrm{kg}]\end{array}$ & 75 & 80 & $\begin{array}{l}\mathrm{b} / \mathrm{d} \\
\mathrm{n} / \mathrm{a}\end{array}$ \\
\hline $\begin{array}{l}\text { Total number of passengers } \\
{[-] \text { / Całkowita liczba pasaż- }} \\
\text { erów [-] }\end{array}$ & $\begin{array}{l}376 \\
\div 524\end{array}$ & $\begin{array}{l}281 \\
\div 376\end{array}$ & $\begin{array}{l}257 \\
\div 341\end{array}$ \\
\hline $\begin{array}{l}\text { Total mass of the passengers } \\
{[\mathrm{t}] / \text { Całkowita masa pasaż- }} \\
\text { erów [t] }\end{array}$ & $\begin{array}{l}25,6 \\
\div 35,7\end{array}$ & $\begin{array}{l}21,1 \\
\div 28,2\end{array}$ & $\begin{array}{c}18,0 \\
\div 23,9\end{array}$ \\
\hline
\end{tabular}

Car bodies of particular sections were made of friction stir welded aluminium extrusion panels (Fig. 14). In the same time, those panels are vehicle body shell, so total car body weight and production time can be reduced, on the other hand, a repair of such construction is time and money consuming. Aluminium extrusion profiles were welded to panels' surfaces and to them seats, handrails, interior ceiling panels and some walls panels (most of them are directly stick to the car body construction) are mounted by bolt connections. Such connection consists of special thread nut which position can be adjusted by shifting it inside a profile, so particular elements can be precisely fixed. Different build characterizes the driver's cab which construction consists of an aluminium welded frame covered with glass fiber reinforced plastic panels.

Vehicle's open floor design was ensured, thanks to a use of gangways which consist of a bridge system shielded by plastic double-corrugated bellows. Particular vehicle sections are fixed to each other by articulation joints (Fig. 15).

A particular joint contains two washers (one per section), between which is situated a composite sliding washer. This insert washer is equipped with lubrication grooves and holes, which are responsible for quiet and smooth work with low wear. Polymer cover (from top) and two-lip seal (from bottom) are used to seal the whole construction. Central bolt is responsible for construction integrity and it prevents the car body sections to climb on each other e.g. during extensive braking. Two articulation joints are used between both car body sections (top and low) that were necessary because of high vertical forces acting on both joints. Such load values result from partial support of end sections on the middle one.

\subsection{Suspension system}

Every vehicle section is suspended under bogie by a pair of columns (Fig. 16), which are integral car body parts. Those columns are inelastically fixed in the suspension frame, so necessary flexibility between the paneli aluminiowych (rys. 14). Panele te, stanowiące jednocześnie poszycie zewnętrzne wagonu, pozwalają na obniżenie jego masy całkowitej oraz skrócenie poszczególnych etapów produkcyjnych. Jednocześnie naprawa, wykonanej w ten sposób zintegrowanej konstrukcji, jest praco- i czasochłonna. Dodatkowo do powierzchni paneli dospawano profile aluminiowe, stanowiące miejsca mocowania foteli, uchwytów, paneli sufitowych, czy niektórych paneli ściennych (większość jest bezpośrednio klejona do powierzchni nośnej pudła). Montaż poszczególnych elementów odbywa się za pomocą złączy śrubowych składających się ze specjalnych gwintowanych nakrętek, których położenie może być regulowane poprzez przesuwanie ich we wnętrzu odpowiednich profili, co pozwala na dokładne pozycjonowanie mocowanych elementów. Odmienną budową charakteryzuje się przedział maszynisty, gdzie funkcję konstrukcji nośnej pełni aluminiowa rama, pokryta od zewnętrz panelami $z$ tworzywa sztucznego wzmocnionego włóknem szklanym. Jednoprzestrzenne wnętrze pojazdu zapewniono poprzez zastosowanie połączeń międzyczłonowych, osłoniętych przy użyciu przejścia harmonijkowego wykonanego z tworzywa sztucznego. Poszczególne człony połączono przy pomocy przegubów (rys. 15).

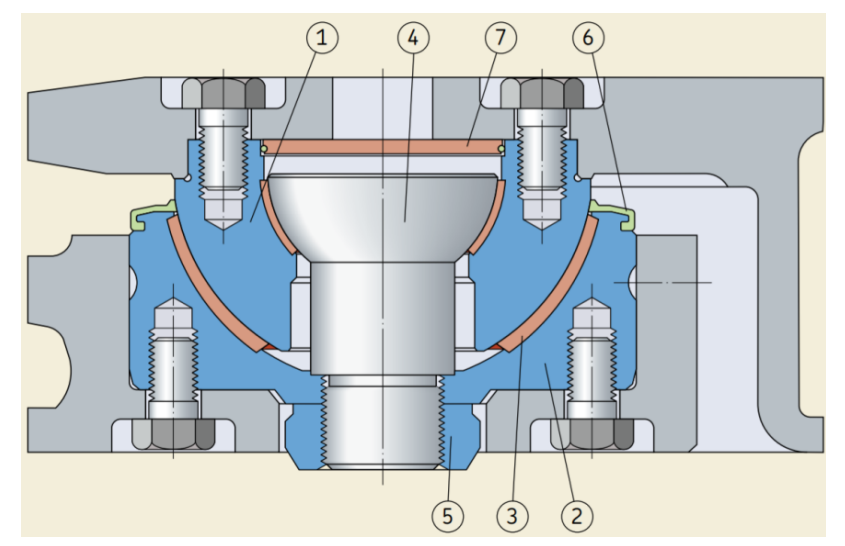

Fig. 15. Articulation joint [16]

Rys. 15. Przegub międzyczłonowy [16]

1. Shaft washer / Czasa górna;

2. Housing washer / Czasza dolna;

3. Insert of housing washer / Wkładka ślizgowa;

4. Central bolt / Śruba centralna;

5. Lock nut / Nakrętka;

6. Flexible two-lip seal / Uszczelka wargowa;

7. Polimer cover / Pokrywa polimerowa.

Przegub tego typu złożony jest $\mathrm{z}$ dwóch czasz (po jednej na człon) rozdzielonych kompozytowymi wkładkami ślizgowymi, wyposażonymi w rowki i otwory smarujące, które zapewniają cichą i płynną pracę oraz zmniejszają zużycie. Całość konstrukcji uszczelniona jest od góry - pokrywą polimerowa, i od boków - uszczelką wargową, a jej integralność zapewnia centralna śruba, zabezpieczająca skład przed nabieganiem na siebie kolejnych członów. Pomiędzy sąsiednimi członami zastosowano dwa przeguby (dolny i górny), co było konieczne ze względu na ich 
car body and the bogie is obtained by bogie's secondary suspension. In such case, a suspension frame can be treated as integral car body part.

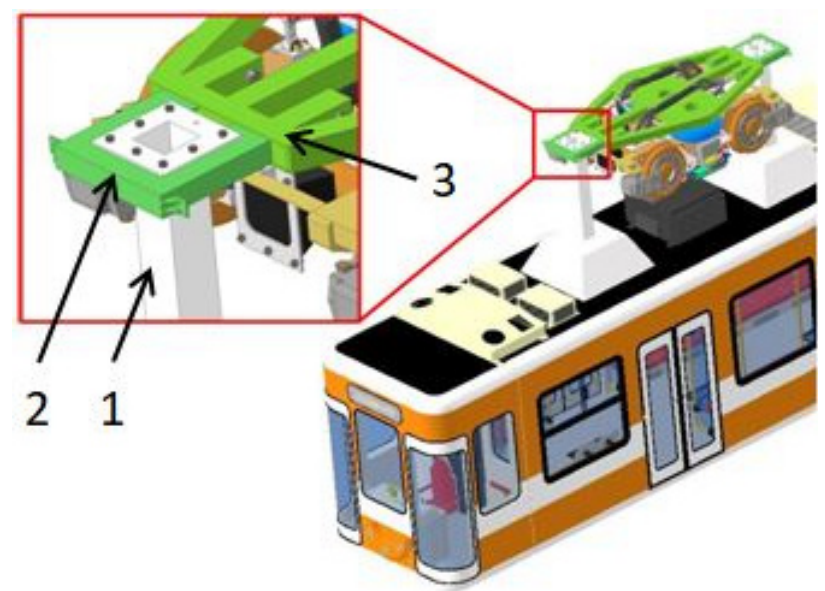

Fig. 16. Car body suspension [14]

Rys. 16. Podwieszenie pudła wagonu [14]

1. Car body column / Kolumna nadwozia;

2. Column attachment / Mocowanie kolumny;

3. Suspension frame / Stelaż podwieszenia.

Authors' suspension concept consists of: a column, a column attachment and the suspension frame. In this system, a column flange is supported by the column attachment, so the bolt connection is loaded only by longitudinal forces instead of vertical forces, which result from the total car body weight. Similarly, the bolt connection, between column attachment and suspension frame, is sheared. This type of configuration is obliged to following assembly order (Fig. 17):

- an elevation car body with use of a hydraulic lift;

- an insertion of a column attachment into the mounting holes of the suspension frame;

- bolting a column attachment to the suspension frame (bolt connection prevents relative movement between mentioned elements);

- supporting the car body on the column attachment;

- bolting a column to its attachment.

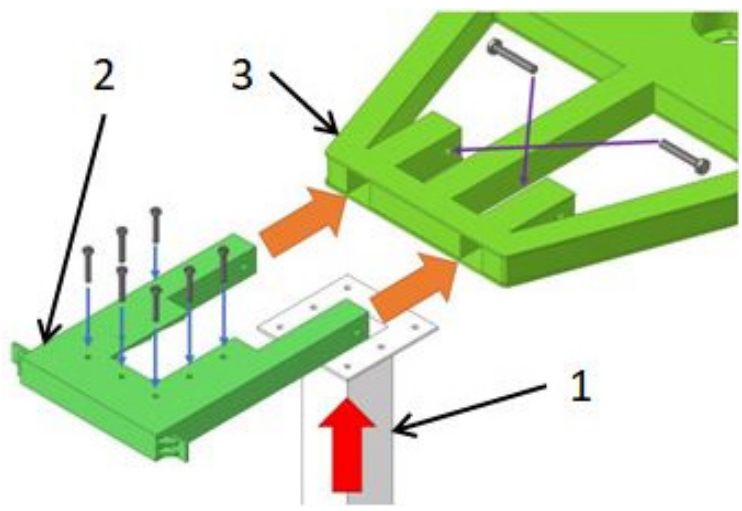

Fig. 17. Suspension system assembly [14] Rys. 17. Montaż układu podwieszenia [14] 1. Car body column / Kolumna nadwozia;

2. Column attachment / Mocowanie kolumny;

3. Suspension frame / Stelaż podwieszenia. znaczne obciążenie pionowe, wynikające z częściowego oparcia członów skrajnych na członie środkowym.

\subsection{System podwieszenia pojazdu}

Każdy z członów podwieszony jest pod wózkiem za pomoca pary kolumn (rys. 16), będących integralna częścią pudła wagonu. Kolumny te są niesprężyście mocowane $\mathrm{w}$ stelażu podwieszenia, a wymagana podatność pomiędzy pudłem wagonu i wózkiem, realizowana jest poprzez sprężyste oparcie stelaża podwieszenia na wózku. W takim przypadku można traktować wspomniany stelaż jako część nadwozia.

Opracowany system podwieszenia złożony jest $\mathrm{z}$ trzech zasadniczych elementów: kolumny, mocowania kolumny oraz stelaża podwieszenia. W systemie tym zdecydowano się na oparcie kołnierza kolumny na jej mocowaniu, dzięki czemu złącze śrubowe łączące oba elementy przenosi jedynie obciążenia wzdłużne, a nie pionowe pochodzące od masy całkowitej pudła wagonu. Również połączenie śrubowe przy stelażu podwieszenia pracuje wyłącznie na ścinanie. Jednocześnie taka konfiguracja wymusza odpowiednią kolejność montażu (rys. 17) poszczególnych elementów i tak konieczne jest:

- uniesienie pojazdu przy pomocy podnośników hydraulicznych;

- wsunięcie mocowania kolumny do otworów montażowych w stelażu podwieszenia;

- dokręcenie mocowania kolumny do stelaża (złącze śrubowe zapobiega ruchom względnym pomiędzy mocowaniem kolumny a stelażem);

- oparcie nadwozia na mocowaniu kolumny;

- dokręcenie kolumny do jej mocowania.

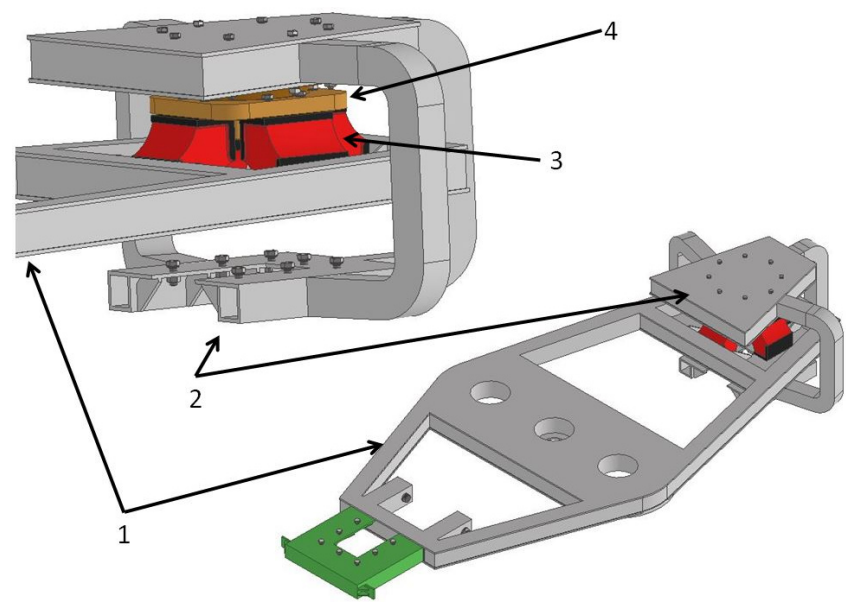

Fig. 18. Suspension frame of Jacobs bogie [14] Rys. 18. Stelaż podwieszenia wózka Jacobsa [14]

1. Suspension frame / Stelaż podwieszenia;

2. Column attachment / Mocowanie kolumny;

3. Spring / Sprężyna metalowo-gumowa;

4. Spherical centre bowl / Czop skrętu.

Jednym z potencjalnych problemów dotyczących wytrzymałości belki jezdnej jest wartość maksymalnego nacisku zestawu kołowego na tor, wynosząca 11,9 t. 
Relatively high pressure of a wheelset on the track, maximally equals $11,9 \mathrm{t}$, could cause potential problems with strength of the guideway beam. Aforementioned value can be reduced by an increase of number of axles that could be achieved by the use of two Jacobs bogies. Those bogies construction must ensure car body sections relative movements. For this purpose, suspension system was modified (Fig. 18) by changing the middle section column attachment construction (additional car body A column would be mounted in the same way as it was described earlier).

In the modified column attachment a centre pivot is used which cooperates with a spherical centre bowl (an element made of cast steel, covered inside with a friction lining) that is supported by metal-rubber springs located on the suspension frame and providing elastic connection. Centre pivot ensures not only a relative rotation of connected elements but also a transmission of loads (longitudinal, vertical and transverse). Additional advantage of such construction is a reduction of vertical load acting on articulation joints.

\subsection{The bogie}

The bogie construction is presented in Fig. 19 with and without suspension frame. This suspension frame is treated as an integral part of the car body, so it is a place of mounting the equipment, like dampers, which normally directly cooperate with the rolling stock car body.

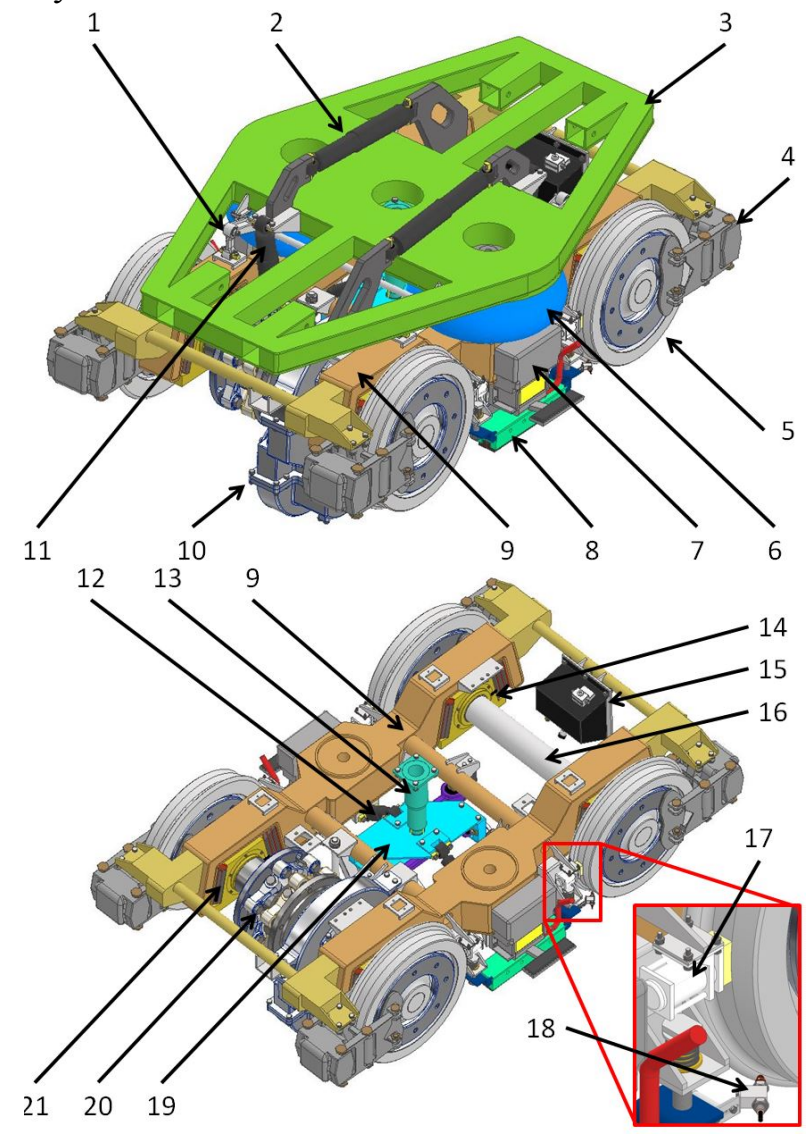

Fig. 19. Bogie components [14]

Rys. 19. Budowa wózka [14]
Wartość tą można zmniejszyć poprzez zwiększenie liczby wózków do czterech. Wymaga to jednak zastosowania dwóch wózków międzyczłonowych (tzw. wózków Jacobsa), których konstrukcja musi umożliwiać względną swobodę ruchu pomiędzy członami. W tym celu niezbędne jest zmodyfikowanie systemu podwieszenia (rys. 18), poprzez zmianę konstrukcji mocowania kolumny członu środkowego (dodatkowa kolumna członu A zostałaby zamocowana w analogiczny, do wcześniej omawianego, sposób).

W zmodyfikowanym mocowaniu kolumny zostałby zamontowany czop skrętu współpracujący ze swoim gniazdem (element staliwny wyłożony okładziną cierna) opartym na wielkogabarytowych sprężynach metalowo-gumowych spoczywających na stelażu podwieszenia, a zapewniających odpowiednią podatność połączenia. Czop skrętu umożliwia nie tylko obrót elementów względem siebie, ale również przenosi obciążenia wzdłużne, pionowe i poprzeczne. Dodatkową zaletą takiej modyfikacji konstrukcji jest zmniejszenie obciążenia oddziaływującego na przeguby międzyczłonowe.

\subsection{Wózek}

Konstrukcję zaprojektowanego wózka prezentuje rys. $19 \mathrm{w}$ dwóch wariantach, to jest kolejno $\mathrm{z}$ oraz bez stelaża podwieszenia. Stelaż ten, traktowany jako integralna cześć pudła wagonu, jest miejscem mocowania podzespołów współpracujących z nadwoziem pojazdu, takich jak np. tłumiki drgań.

Wózek, którego wybrane dane techniczne zostały zestawione w tabeli 7 [14], zostanie skrótowo opisany przy pomocy listy punktowej:

- wewnętrzna rama wózka, o trójobwodowej zamkniętej konstrukcji przestrzennej, pozwala na zmniejszenie jego masy całkowitej oraz wymiarów gabarytowych (determinujących wymiary belki jezdnej)

- krótka baza, zapewnia dobre wpisywanie się wózka w łuki torowe

- w maźnicach ułożyskowano zestawy kołowe za pomocą zespołów stożkowych łożysk tocznych, fabrycznie uszczelnionych i wyposażonych w czujniki systemu diagnostycznego (pomiar temperatury, częstotliwości drgań oraz prędkości obrotowej)

- sprężyny metalowo-gumowe typu klinowego jednocześnie pełnią funkcję usprężynowania I stopnia i prowadzenia zestawów kołowych, a odpowiedni dobór ich sztywności pozwala na quasi-radialne ustawienie się zestawów kołowych w łuku torowym (zmniejszenie kąta nabiegania)

- sprężyny pneumatyczne w II stopniu usprężynowania, współpracują ze stabilizatorem przechyłu poprzecznego nadwozia (zwiększa sztywność poprzeczną usprężynowania) oraz z hydraulicznymi thumikami drgań 
1. Anti-roll bar / Stabilizator przechyłu poprzecznego nadwozia;

2. Damper of hunting motion / Tłumik wężykowania;

3. Suspension frame / Stelaż podwieszenia;

4. Disc brake unit / Zacisk hamulca tarczowego;

5. Wheelset / Zestaw kołowy;

6. Air spring / Sprężyna pneumatyczna;

7. Current collector / Odbierak prądu;

8. Magnetic track brake / Elektromagnetyczny hamulec szynowy;

9. Bogie frame / Rama;

10. Mechanical gear / Przekładnia mechaniczna;

11. Vertical damper / Tłumik pionowy;

12. Horizontal damper / Tłumik poziomy;

13. Centre pivot / Czop skrętu;

14. Axlebox / Maźnica;

15. Grease reservoir / Zbiornik smaru;

16. Axle of the wheelset / Oś zestawu kołowego;

17. Wheel tread cleaning unit / Blok czyszczący;

18. Lubrication nozzle / Dysza smarująca;

19. Watts linkage / Układ lemniskatowy;

20. Coupling / Sprzęgło;

21. Chevron spring / Sprężyna metalowo-gumowa typu klinowego.

The bogie, which technical specification is presented in Table 7 [14], is shortly described by a point list:

- internal, three-section, closed space frame reduces total bogie weight and dimensions (which determine guideway beam dimensions);

- short wheelbase ensures good running performances in curved track;

- compact tapered roller bearing units are used to support wheelsets in axleboxes housings. Every bearing is sealed in a factory and is equipped with diagnostic sensors (allowing a measurement of: rotational speed, temperature and vibration frequency);

- primary suspension chevron springs are also used to wheelset guidance, so correct selection of springs stiffness allows a quasi-radial adjustment of wheelsets in a track curve (resulting in wheelrail attacking angle reduction);

- air springs in secondary suspension cooperate with anti-roll bar (which increases secondary suspension stiffness) and hydraulic dampers;

- tractive force transmission between the bogie and the car body (suspension frame) is realized by a pair of traction rods, which are connected to the yoke in a lemniscate system (so-called Watts linkage structure). Pivot socket with friction lining is located in the yoke, to which hydraulic horizontal dampers are mounted. Pivot is fixed to suspension frame. Yoke transverse movements are limited by a pair of buffers;

- propulsion system contains a longitudinally placed traction motor and two-stage, helical-bevel gear unit. All those elements are suspended in the bogie frame. Driving torque is transmitted from gearbox output, hollow shaft to wheelset axle (which passes through inner hole of mentioned shaft) via constant velocity transmission clutch. This clutch consists of links and inter-clutch shaft that permits
- przenoszenie sił trakcyjnych z wózka na nadwozie (stelaż podwieszenia) jest realizowane przy pomocy pary cięgien trakcyjnych połączonych z jarzmem w układzie lemniskatowym. Do jarzma, wyposażonego w wyłożone okładziną cierną gniazdo czopa skrętu, zamocowano thumiki drgań poziomych. Sam czop skrętu jest sztywno zamontowany w stelażu podwieszenia. Ruch poprzeczny jarzma ogranicza para odbijaków

- układ napędowy składa się ze wzdłużnie usytuowanego silnika trakcyjnego i dwustopniowej, stożkowo-walcowej przekładni mechanicznej, razem zawieszonych $\mathrm{w}$ ramie wózka. Moment napędowy przenoszony jest $\mathrm{z}$ wyjściowego wału drążonego przekładni na oś zestawu kołowego (przechodzącej we wnętrzu wspomnianego wału) za pośrednictwem równobieżnego sprzęgła cięgnowego $\mathrm{z}$ wałem międzysprzęgłowym, kompensującym osiowe, promieniowe oraz kątowe przemieszczenia pomiędzy wałem przekładni i osią. Elementy gumowe $\mathrm{w}$ łbach cięgien wytłumiaja drgania. Również silnik z przekładnią łączy gumowe sprzęgło podatne

- położenie osi silnika na płaszczyźnie przechodzącej przez obie główki szyn, było konieczne ze względu na duże przełożenie przekładni, a jest możliwe dzięki jednostronnemu rozcięciu belki jezdnej

- jedynie jedna oś napędna jest efektem wykorzystania przekładni o dużym przełożeniu i silnika dużej mocy (duże wymiary gabarytowe) w wózku o wewnętrznej ramie oraz krótkiej bazie. W celu uzyskania wystarczającej mocy całkowitej pojaz$\mathrm{du}$, konieczne było zastosowanie nietypowego układu osi pojazdu

- dwie płozy elektromagnetycznego hamulca szynowego, podatnie zawieszone w ostojnicach ramy są bezpośrednio dociskane do główki szyny, a więc generowana przez nie siła hamowania jest niezależna od zjawisk przyczepności na styku koło-szyna

- cztery zaciski hamulca tarczowego, którego tarcze mocowane są na kołach, realizują we współpracy $\mathrm{z}$ hamulcem elektrodynamicznym (który wykorzystuje prądnicową pracę silników trakcyjnych do transformacji energii pojazdu w energię elektryczną gromadzoną w bateriach superkondensatorów) hamowanie robocze

- sterowanie elektropneumatycznym hamulcem tarczowym typu bezpośredniego (w układzie pneumatycznym nie występuje przewód główny) może obywać się za pośrednictwem sterownika hamowania wchodzącego w skład mikroprocesorowej sieci pojazdu lub też za pomocą dodatkowego, niezależnego układu elektronicznego. W ten sposób zapewniono wymaganą redundancję sterowania 
- compensation of axial, radial and angular displacements. Flexible bushes in the links prevent vibration transmission. Moreover, motor is connected to gear unit via elastic clutch;

- the position of the motor axis on the plane passing through both railheads was necessary because of gearbox high ratio. Such motor placement was possible thanks to the one-sided open guideway beam;

- only one bogie axle is powered, that is due to use of high ratio gearbox and high power motor (large overall dimensions) in bogie with internal frame and short wheelbase. Therefore, to ensure high total vehicle power, unusual axle arrangement was necessary to use;

- two independent drag shoes of track brake are elastically suspended in the bogie frame. In this kind of brake, the brake force value is completely independent from wheel-rail adhesion phenomena, thanks to the fact that drag shoe is directly pressing against railhead;

- four wheel-mounted disk brake units and regenerative brake (traction motor works as a generator and enables a transformation of vehicle's energy into electric energy which is collected in battery of supercapacitors) are blended to realize service brake;

- direct electro-pneumatic disc brake system (pneumatic system is not equipped with a brake pipe) is controlled by the brake control unit, which is a part of the vehicle's microprocessor system, or by independent electronic system. In this way control redundancy is obtained;

- tread cleaning units are used for conditioning of wheel treads;

- flange lubrication system improves vehicle parameters in curved track (higher safety and lower: noise emission, motion resistance or wear of wheels and rails).

Bogie construction and strength analysis of its important components will be precisely described in another publications.

\section{SUMMARY}

This cursory article describes only concept of suspended vehicle, so proposed solutions should be once again thoroughly analysed. In further development of the electric suspended multiple unit, such issues as vehicle kinematics and dynamics, electronic systems or infrastructure require more precise study.

Moreover, only static strength analysis was conducted on the car body and its suspension system, so in the future those calculations should be expanded to fatigue and dynamic cases, which probably would impose changes of the construction.

Authors hope that this brief article will popularise suspended monorails and it becomes a source of
- bloki czyszczące kondycjonują powierzchnie toczne kół

- układ smarowania obrzeży, poprawia warunki ruchu w łukach torowych (zwiększenie bezpieczeństwa, zmniejszenie: hałasu, oporów ruchu oraz zużycia kół i szyn).

Szczegółowy opis konstrukcji wózka oraz analiza wytrzymałościowa jego wybranych podzespołów będą przedmiotem osobnych publikacji.

Table 7 Technical specification of vehicle's bogie Tabela 7 Wybrane dane techniczne wózka pojazdu

\begin{tabular}{|l|c|c|}
\hline Feature / Cecha & $\begin{array}{c}\text { Unit / } \\
\text { Jednostka }\end{array}$ & $\begin{array}{c}\text { Value / } \\
\text { Wartość }\end{array}$ \\
\hline Track gauge / Rozstaw szyn & $\mathrm{mm}$ & 1435 \\
\hline Length / Długość & $\mathrm{mm}$ & 2926 \\
\hline Width / Szerokość & $\mathrm{mm}$ & 1789 \\
\hline Height / Wysokość & $\mathrm{mm}$ & 1151 \\
\hline Wheelbase / Baza wózka & $\mathrm{mm}$ & 993 \\
\hline $\begin{array}{l}\text { Distance of springs sets of primary } \\
\text { suspension / Rozstaw sprężyn I st. }\end{array}$ & $\mathrm{kg}$ & 1068 \\
\hline $\begin{array}{l}\text { Distance of spring sets of secondary } \\
\text { suspension / Rozstaw sprężyn II st. }\end{array}$ & $\mathrm{kg}$ & 1108 \\
\hline $\begin{array}{l}\text { Total mass of the bogie / Całkowita } \\
\text { masa wózka }\end{array}$ & $\mathrm{kg}$ & 4367 \\
\hline $\begin{array}{l}\text { Unsprung bogie mass / Masa nie- } \\
\text { usprężynowana }\end{array}$ & $\mathrm{kg}$ & 829 \\
\hline $\begin{array}{l}\text { Suspended bogie mass by the pri- } \\
\text { mary suspension / Masa } \\
\text { usprężynowana I st. }\end{array}$ & 11,97 \\
\hline $\begin{array}{l}\text { Suspended bogie mass by the sec- } \\
\text { ondary suspension / Masa } \\
\text { usprężynowana II st. }\end{array}$ & & \\
\hline $\begin{array}{l}\text { Pressure of the wheelset on a track / } \\
\text { Nacisk osi na tor }\end{array}$ & $\mathrm{k}$ & \\
\hline
\end{tabular}

\section{PODSUMOWANIE}

Powyższy artykuł ma charakter poglądowy, a proponowane w nim rozwiązania wymagają dogłębnej analizy. W toku dalszych prac rozwojowych należałoby między innymi szerzej rozpatrzyć zagadnienia związane z kinematyką, dynamiką, elektroniką pojazdu oraz infrastruktura.

Ponadto zarówno pudło wagonu jak i system jego podwieszenia zostały poddany wyłącznie statycznej analizie wytrzymałościowej, którą w przyszłości należałoby rozszerzyć o aspekty związane z wytrzymałością zmęczeniową, czy obciążeniem dynamicznym, co z pewnością skutkowałoby ich przeprojektowaniem. Autorzy żywią nadzieję, że niniejsza publikacja przyczyni się w pewnym stopniu do rozpropagowania kolejowych pojazdów podwieszanych i stanie się zaczątkiem dyskusji na temat kierunków dalszego rozwoju ich konstrukcji oraz zastosowania w przestrzeni miejskiej.

discussion about further development of possible constructions and urban applications. 


\section{BIBLIOGRAPHY / BIBLIOGRAFIA}

1. Hino Y.: Monorail and Urban development In Japan; Japan Monorail Association - prezentacja multimedialna.

2. $\quad$ Broszura informacyjna firmy SKF: Technical face lift AT Wuppertal Suspension Railway, wrzesień 2018.

3. Strona internetowa: https://schwebebahn.de/en/ (dostęp na 10.10.2020).

4. Broszura informacyjna firmy Knorr-Bremse AG: Wuppertal, Schwebebahn; 2016.

5. Strona internetowa: https://press.zf.com/press/de/releases/release_2758.html (dostęp na 17.09.2019).

6. $\quad$ Ebmeyer J., Zwank M.: Neue Fahrzeuge der Wuppertaler Scgwebebahn; prezentacja firmy Vossloh Kiepe.

7. Broszura informacyjna: Outline of Shonan Monorail; Shonan Monorail, LTD.

8. Strona Internetowa: http://www.citytransport.info/Monorail.htm (dostęp na 17.09.2019).

9. Strona internetowa: https://railf.jp/event/2018/12/21/134500.html (dostęp na 17.09.2019).

10. Demery L.: Monorails in Japan: An Overview publictransit.us Special Report No. 9; June 22,2005.

11. Raport techniczny Mitshubishi Heavy Industries: Chiba Urban Monorail „,Urban Flyer”; Vol.47 No.2 (2010).

12. Liu X., Sun H., Liu F.: Study on the Application and Development of Monorail Transit System; IJERT Vol 3 Issue5.

13. Strona internetowa: https://kamakura-enoshima-monorail.jp/fun/index.html (dostęp na 07.10.2020).

14. Jędrzejewski P., Kuczyk M.: Koncepcja wagonu silnikowego kolei podwieszanej; praca magisterka, Gdańsk 2020.

15. Uhl T., Hanc A., Dlugaszek D., Szromek A.: Rzeczywiste obciażenie tramwajów w ruchu miejskim; TTS, 4/2004.

16. Publikacja firmy SKF: Railway technical handbook, volume 1; lipiec 2011. 